\title{
Mapping and Cartography Futures in Secondary Geography
}

\section{Lex Chalmers}

\section{ABOUT THE AUTHOR}

Lex Chalmers is Associate Professor of Geography, The University of Waikato.
In an era of change such as that induced by the NCEA, questions about the role and relevance of traditional skills tend to be overlooked. In my opinion, an important component in our 'bank of skills' (Ministry of Education, 1990, 17; New Zealand Geographical Society, 1992, 10-11) are threatened by institutional sidelining and lack of awareness of the potential for their technological resuscitation. With reference to skills, the use of prepared maps and map construction (cartography) are fundamental geographic skills. Having asserted this, I also want to make it clear that, in my view, these skills should be as broadly applied as possible.

The Explanatory Notes of NCEA AS90505 (Geography 1.4) describe the derivation of the standard (New Zealand Qualifications Authority, 2002), but a source of concern to me personally is the dated nature of the resources available to support teaching in the areas of mapping and cartographic skill. Stella Bond's (1997) text is an excellent classroom resource, devoting more than 35 pages to mapping and cartography skills, but there is a danger in using the classroom resource as a driver of the syllabuses we teach. Our focus on assessment has perhaps distracted us from curriculum review and the on-going professional development we need to undertake, once we have guidelines on contemporary map use and cartography. These issues are exacerbated when we consider that some geography teachers have little formal geography training in their degrees. The universities and national mapping agencies also offer little support; skillsbased courses like Cartography 101 have diminished roles in the undergraduate degree, and cartographic leadership from the Department of Lands and Survey is just a distant memory.

With reference to skills "using prepared maps" (New Zealand Geographical Society, 1992,10) the standard NZMS topographic map has dominated our teaching for decades. In my view books of maps (or atlases) have been neglected as sources of ideas of what can and should be mapped. The value of the conventional thematic atlas as a geographic tool is explored in Kirkpatrick's (1999) broad retrospective view of the national atlas projects (including McLintoch (1960) and Wards (1976)). Recent collections of national data mapped in atlases have moved the genre into new territories. For example, the Historical Atlas of New Zealand (McKinnon, 1997), The Contemporary New Zealand Atlas (Kirkpatrick, 1999), New Zealand from Space (Bradley, 2000) and Degrees of Deprivation (Crampton et al. 2000) all contain 'maps' on new thematic topics using a variety of interesting mapping techniques with the potential to stimulate discussion in almost any classroom context.

In my view, these resources have not yet become classroom standards, and until we introduce them, our efforts to convey 
the importance of maps will seem dated. Our learners experience a technologic world; the extent to which the computer screen (or more charming Visual Display Unit) has replaced the printer is echoed in the move from Cartesian referencing of topographic features towards the visualising of space and place from differing perspectives. Once the mapping principles covered in Bond (1997) become familiar, the excitement of maps that work differently can enliven our classrooms.

There are better texts for learning about map making and cartography than those available on my shelf. Some techniques have not changed since the days of Monkhouse and Wilkinson (1964) and Dickinson (1973), but more recent texts such as Keates (1989) and Dent (1996) focus more on design and map production technologies. Bond $(1997,20)$ describes an approach to three précis map. This form of map has dominated our teaching of cartography in geography for decades; it has been an important part of our assessment system, and it is hard to imagine a School Certificate, Bursary or the NCEA Achievement Standard external examination without such a task.

Again, however, we need to take into account the technological options that are available. Such a suggestion may seem at first to disenfranchise those teachers and classrooms without access to state-of-the-art computing. While the options available within software such as ArcView provide tools for almost any sort of representation, given teacher training, time in the classroom and available facilities, Ido not think student use of GIS for making maps will be routine within the next five years. However, simple tools like Powerpoint are really useful in classroom map production, and teachers doing professional development courses at Waikato University have taken to the idea of using a conventional drawing tool for new forms of cartographic production.

With professional development in mind, GIS awareness seems to have found a new life in 2002. Courses run nationally by Anne Olsen and Stephanie Eddy (Page 5, NZBoGT Newsletter, Term 3, Issue 17) have been both popular and well received by a significant number of teachers. If teachers need to see where the map making technology is going, the ESRI (2002) map book provides some impressive exemplars of what can be done in this domain. Maps like the visualisations of the Salton Sea (ESRI, 2002, 91) and Mono
Lake (ESRI, 2002, 94) in California are excellent examples of what can be done. While it may be some time before we see Lake Bruner or the Taupo Volcanic zone in 3-D on our own machines, such visualisations techniques are available and will provide great classroom resources for secondary and tertiary geographers.

Given the resource limits and distractions of so many changes in the classroom, my views on the nature of change in the classroom are modest. My comments relate to the syllabus and assessment framework as it is, rather than as it should be. I have not considered what could be done if we started afresh, nor whether (as my friends suggest) cartography has outgrown geography, and the relationship is no longer symbiotic.

So, my opinion is that any prescription for a review of 'using prepared maps' and/or 'map construction' must be based on negotiated change of the existing frameworks, as much as we might prefer a more radical transformation. Even so, there are impediments to negotiated change; the Ministry of Education has resisted the best efforts of the New Zealand Board of Geography Teachers to sponsor a review of the Geography syllabus and has stated that this will not be undertaken. Requests for resources to update G6: Skills in Geography has also failed to attract Ministry support. If we are to make changes in the way we think about skills in using maps and cartography, we have options of adopting models from elsewhere, and/or contracting to meet our needs. AGTA and the NZBoGT have shown this can be done although the focus of these developments was resources for classroom use, rather than a profession development option.

I think we should also use our natural allies in this process; three such agencies spring to mind. The New Zealand Cartographic Society is running an International Conference in Wairakei next year, and they have a strong interest in seeing map use and cartography promoted in secondary/ tertiary education (see the Awards and CartoSchool pages on the site www.cartography.org.nz). The International Geographical Union is sponsoring a competition at Glasgow in 2004. Finally, the AURISA competition has been running for a number of years (www.aurisa.asn.au/education/ GISschoolsComp.htm). All these agencies can and should be involved in the promotion of cartography in geography.

\section{References}

Bond, S. 1997: Social Sciences Skills, New House Publishers, Auckland.

Bradley, B. 2000: New Zealand from Space, Penguin Books, Auckland.

Crampton, P., Salmond, C. and Kirkpatrick, R. 2000: Degrees of Deprivation: An Atlas of Socioeconomic Difference, David Bateman, Auckland.

Dent, B. D. 1996: Cartography: Thematic Map Design, Wm. C. Brown Publishers, Dubuque.

Dickinson, G. C. 1973: Statistical Mapping and the Presentation of Statistics. Edward Arnold, London.

ESRI 2002: Geography and GIS - sustaining our world, ESRI Map Book Volume 17.

Keates, J. S. 1989: Cartographic Design and Production John Wiley and Sons, New York.

Kirkpatrick, R: 1999: Contemporary Atlas of New Zealand, Bateman, Auckland.

McKinnon, M. 1997: New Zealand Historical Atlas- Ko Papatuanuku e Takoto Nei. Bateman, Auckland.

McLintoch, A. H. 1960: A Descriptive Atlas of New Zealand, Government Printer, Wellington.

Ministry of Education 1990: Syllabus for Schools: Geography Forms 5-7. Learning Media, Wellington.

Monkhouse F. J. and Wilkinson, H. R. 1964: Maps and Diagrams, Methuen, London.

New Zealand Geographical Society 1992: G6: Skills in Geography. Christchurch.

New Zealand Qualifications Authority 2002: Achievement Standard AS90205 at www.nzqa.govt.nz/ncea/ach/geography/AS90205.doc

Wards, I. M. 1976: New Zealand Atlas. Government Printer, Wellington. 